\title{
Analysis of Microfinance Institution Outreach on the Realization of Economic Pillar of Vision 2030: A Case of Kakamega County
}

\author{
Sangoro Oscar* \\ School of Business and Economics, Mount Kenya University \\ P. O Box 553-50100, Kakamega, Kenya \\ Gongera George \\ School of Business and Economics, Cooperative University \\ P. O Box 24814-00502, Karen, Kenya \\ Ronald Onsiro Ronald \\ School of Business and Economics, Mount Kenya University \\ P. O Box 342-01000, Thika, Kenya
}

\begin{abstract}
This paper sought the analysis of microfinance institutions outreach on the realization of economic pillar of vision 2030. Microfinance institution outreach in this study is checked in terms of breadth and depth. In line with economic pillars for vision 2030, MFIs are vital in advancing credit to the communities which are financially constrained but have feasible, practicable and promising investment business ideas. This study was carried in Kakamega County which has very high level of poverty. This study adopted Cross-sectional research design and correlation design. The target population in this study consist of businesses deriving their capital from 15 microfinance institutions both small scale and medium scale, Employees of MFIs comprising of branch manager, credit officer, risk officers and operational manager. The results indicated that MFI outreach had a statistically significant influence on the realization of vision 2030 in Kakamega. The study concluded that MFI outreach had significant positive influence on the realization of economic pillar of vision 2030
\end{abstract}

Keywords: Microfinance institution, Outreach, Vision 2030, Economic Pillar

DOI: $10.7176 /$ RJFA/10-16-08

Publication date: August $31^{\text {st }} 2019$

\section{Introduction}

The social obligation of MFI is to make financial services available to the poor through outreach programmes. MFI outreach is defined in terms of breadth and depth of financial services advance to their clients. According to Jay (2010) outreach is central in MFIs activities as its outlines its vision in improving lives of its clients. In line with economic pillars for vision 2030, MFIs are vital in advancing credit to the communities which are financially constrained but have feasible, practicable and promising investment business ideas. Increasing MFI outreach results to providing credits to many clients who start various income generating activities while at the same time MFIs enjoy economies of scales translating to MFI growth and sustainability. However, this requires adequate funding to facilitate reaching to communities where poverty is prevalent with aim of improving their socioeconomic status. It's worthwhile to examine the influence of MFI outreach in the realization of vision 2030.

\subsection{LITERATURE REVIEW}

Extending microfinance services to underserved people who are been locked out by formal financial institutions is classified as outreach. Microfinance outreach is vital on the realization of economic growth and development as it extends financial services to unbanked population for the purpose of income generating activities. Outreach is central in microfinance activities because it defines the visions of MFIs in improving lives of its clients especially the poor. Outreach is determined by how far microfinance as a financial institution has gone to reach those who have been denied formal financial services. The availability of financial services acts as a buffer for sudden emergence business risk, seasonal shrimps or events such as flood or a death in the family that can push a poor family into destitution (Chu, 2008).

According to Lafourcade et al. (2005) the two most common aspects of microfinance outreach are depth and breadth. Depth of outreach is the socio-economic level of MFIs client and it represents the poverty of clients been served by a Microfinance institutions. Breadth is the count of clients served by the MFI and the volume of services in offered in term of total saving and outstanding portfolio. The proponent of MFI outreach should have the mechanism and ability to cover remote and poor areas with aim of promoting unemployed population to create and develop various projects for incoming generating (Malkawi and Atoom, 2011).

The proponents of MFI depth is that the principal aim of MFIs is to serve poor individuals who are omitted from commercial banks credit thus depth is vital for achieving microfinance social objectives of poverty alleviation. 
Depth of outreach accords the gain from microcredit a given borrower from society stands to benefit as a result using micro credit product and services. Proponents of MFI breadth indicated that MFIs should have large scale coverage so that they have wider audience for loans and other financial services. The breadth would make differences in term of poverty level that can be tracked by loans disbursed, saving volume and active numbers of opened accounts (Navajas, Schreiner, Meyer, \& Gonzalez-Vega, 2000). However, shallow depth of MFI can be offset by breadth through the spillover effects. Zeller and Johannsson (2006) revealed that the spillovers are revealed through improved standard living of family members and employment opportunities in the society created by income generating activities by the beneficiaries of micro credit products and services.

Other outreach aspects derived from breadth and depth are worth of outreach, length of outreach, scope of outreach and cost of outreach. The worth of outreach is the willingness of borrower to pay for MFI services. Cost of outreach is the cost such as interest rates and expenses such as transports, food, stationery and taxes a borrower incurs in acquiring a loan product from MFIs (Meyer, 2002). These aspects are related MFI depth of outreach as cost and worth of loan product indirectly influence socio-economic status of borrowers.

Various authors have used different proxies for MFI depth of outreach unlike breadth of outreach. Bereket and Lalitha (2009) and Chemining'wa (2013) used average loan size while Lalitha (2009) used number of active borrowers. Kidzuga (2013) used number of branches and percentage of women borrowers and Magiri (2014) used the net worth of borrowers. Iftekhar et al. (2014) in their study used depth as average loan balance per borrower per GNI per capita. This enables comparison on how microfinance institutions have an effect on national income distribution. According to MIX (2014), loans with outstanding balance below 20\% per capita GNI is a suggestion that borrowers are very poor. According to Quayes (2012), the poverty level of borrower defines the depth of outreach and the income of the borrowers must be assessed. This has led to Copestake (2007) criticizing previous researcher on the outreach depth indicators. According to him, no available data has been collected on the average loan balance per the MFI borrower then divided by gross national income. Therefore, this study used depth of MFI outreach by considering the GNI so as to represent the poverty level of the borrowers and how far MFIs have reached these borrowers.

Basing on the above outreach concepts, the microfinance institutions have the responsibility to reach out to those individual who have been denied or locked out from formal financial services. In the realization of Economic Pillars for Vision 2030, MFI have major responsibility through its outreach program to bring every citizen on board. The output in term social value is its outreach to its clients not only to increase the number of clientele but also to make a difference in their socio-economic status. These aspects of MFI outreach are interlinked as depth is considered the social value of worth to certain group of borrowers minus cost to users. Breadth on the other hand is the social value scope of MFI products which is discounted by the length of time required to acquire the products. Therefore, MFIs outreach is weighted by its depth and summed across the breadth of its clients. Therefore in examining the realization of Economic pillars for vision 2030, MFI outreach is inevitable indicators and in this study found it necessary to assess its influences.

The above empirical studies have revealed that there are various gaps which this study sought the fill in the relationship between MFI outreach and realization of vision 2030. The reviewed literatures has exposed significant gaps to be filled; conceptually, contextually and theoretical. Contextually, most of the previous studies excluded Kakamega County in their research and at the same time this study is grounded on economic pillar of vision 2030. Further, some studies did not consider effect of outreach on MFIs supported business while they focused on financial sustainability of MFIs. Conceptually, the concept of MFI outreach has elicited different approach in proxy for depth of outreach. Some researchers have used number of women and average loan which other researchers have point out some weakness. Therefore, this research, been based on economic pillar for vision 2030 applied average loan size per capita per GNI to determine depth of outreach.

Lastly, there is mixed outcome also in the theoretical aspect of MFI outreach which is considered social mission of MFIs. Some of the researchers revealed that outreach increase the social welfare of the poor while other researchers indicated it limits the ability of MFIs to effectively serve the poorest of poor. In relation to vision 2030, there is need for MFIs to contribute to achievement of vision 2030 and at the same time the MFIs should be sustainable for unforeseeable future. With various studies indicating tradeoff while other failing to identify tradeoff between outreach and MFI performance, this study sought to identify the relation between MFI outreach and realization of Vision 2030. Therefore assess the influence of MFI outreach on the realization of economic pillar of vision 2030 with aim of testing the first research hypothesis which posits there is no significant relationship between the MFI outreach on the realization of economic pillar of vision 2030.

\subsection{Poverty Lending Theory}

The poverty lending theory focuses on reaching out to the poorest of the poor in the society whose main investment is consumption rather than productivity (Honohan, 2004). This group of people requires financial assistance so as to meet their basic needs such as health, education, and clothing among others. Any kind of credit extend will be mainly used for household consumption instead of investment so as to generate return to service the debt 
(Rosenberg, 2003). However, modern MFIs in aim to increase repayment rate for the poorest of poor, they have included auxiliary services such as training on basic business management skills, family planning and health, farming techniques and other training which aims to reduce the community or group vulnerability to financial shocks.

The proponents of Poverty Lending Theory lay a lot of emphasis on MFIs operation meeting their social objectives rather than the source of funds. Therefore, this approach emphasizes on poverty alleviation, the number of clients reached by the MFIs and the empowerment of poorest of the poor economically (Brau \& Woller, 2004). The target segment proposed by the proponents include slum dwellers, rural populations, youth, poor women as well as other vulnerable groups who are excluded from formal lending. The critics of the theory argued focusing on poorest sector of the markets results to high administration costs and inefficiency and there is need for external support to sustain the MFIs (Paxton, 2002).

The theory in its entirety focuses on reaching out to the unbanked population regardless to the sustainability of the MFIs. The outreach in this case is explained in terms of depth (Poverty) and breadth of outreach (number of clients). Therefore, the theory guided the researcher in assessing the influence of MFI outreach on the realization of economic pillar of vision 2030 as the main objective of MFIs is to offer credit services to unbanked group with aim of alleviating them from poverty.

\subsection{RESEARCH METHODOLOGY AND DESIGN}

This study adopted Cross-sectional research design and correlation design. Cross sectional research design provides a 'snapshot' of the outcome and the characteristics associated with it, at a specific point in time.

Correlation design was used in order to find the relationships among the different variables of interest. Correlation design was used in this study.

This study was carried out in Kakamega County which is located in western province of Kenya. Headquarter of this county is Kakamega town. The target population in this study consist of businesses deriving their capital from 15 micro-finance institutions both small scale and medium scale, Employees of MFIs comprising of branch manager, credit officer, risk officers and operational manager.

This research identified two-in-one aggregation or study groups; these are Microfinance Institutions (MFIs) in Kakamega County of the Kenyan republic and the Microfinance Institutions (MFI) clients who are micro and small enterprise operators, particularly those that have benefited at one time or the other from the financial and non-financial services rendered by the MFI in Kakamega county. The study employed research questionnaires, interviews, focus group discussions and document analysis as the main tools for collecting data.

\subsection{Model Specification}

The hypotheses were structured to ascertain the extent to which microfinance facilities can enhance the expansion capacity of small business in the study. This was expressed as:

$\mathrm{H}_{01}$ : There is no significant relationship between the MFI outreach on the realization of economic pillar of vision 2030 .

$\mathrm{H}_{01}$ was modelled as:

$\mathrm{EPV}_{1}=\alpha+\beta_{1} \mathrm{OR}_{1}+$

Where:

$\mathrm{EPV}=$ Economic Pillar of Vision 2030

$\alpha=$ regression constant derived from the y-intercept,

$\beta_{1}$ to $\beta_{13}=$ regression coefficients,

$\mathrm{OR}=$ MFI outreach,

$\varepsilon=$ error term.

\subsection{RESEARCH FINDINGS, ANALYSIS AND PRESENTATION \\ 4.1 Response Rate}

Two set of questionnaires were administered to sample population consisting of MFI and their clients. Seventy five questionnaires were administered to MFI branch manager, Operational manager, credit officers, Risk officers, and sectional heads. Nine of the respondents failed to return leading to $88.0 \%$ response rate. Three hundred and eighty four questionnaires were issued to client of sampled MFI. Three hundred and six were returned. The response rate was $79.69 \%$. Both questionnaires yielded over $60 \%$ of response rate which is satisfactorily according to Mugenda and Mugenda (2008).

\section{MFI outreach and the economic pillar of vision 2030}

The objective of the paper was achieved through testing of the hypothesis: $\mathrm{H}_{01}$ There is no significant relationship between the MFI outreach on the realization of economic pillar of vision 2030. MFI outreach indicator was used as independent variable while Economic Pillars in the Vision 2030 was used as dependent variable. Government policy, Socio-economic factors and political environment were used as intervening variable and therefore their 
role in the relationship between MFI outreach and realization of Economic Pillar for Vision 2030 was also sought. Regression and correlation analyses were done with 0.05 significance level and $95.0 \%$ confidence level. Secondary data which comprised of audited financial records was used to depict trend in microfinance outreach in term of depth, breadth and average loan size.

\subsubsection{Descriptive Results: MFI Outreach}

Descriptive measures included mean and standard deviation. Mean is a measure of central tendency used to describe the most typical value in a set of values. Standard error of mean is a measure of reliability of the study results. It is equal to the standard deviation of the population divided by the square root of the sample size calculated as: $\mathrm{SE}=(\mathrm{SD})$ (of the population)/square root (n). Standard deviation shows how far the distribution is from the mean. The statements were anchored on a five point Likert-type scale ranging from $1=$ strongly disagree to $5=$ strongly agree and respondents from MFI institutions were asked to indicate the extent to which they agreed to the nine statements. The pertinent results are presented in Table 1.

\section{Table 1: Descriptive Data for Outreach}

\begin{tabular}{|c|c|c|c|c|c|c|c|}
\hline $\begin{array}{l}\text { Outreach and the realization of } \\
\text { economic pillar of vision } 2030\end{array}$ & $\begin{array}{l}\text { SD } \\
(\%)\end{array}$ & D (\%) & U (\%) & $A(\%)$ & $\begin{array}{l}\text { SA } \\
(\%)\end{array}$ & Mean & Stdev \\
\hline $\begin{array}{l}\text { There has been increase customers base } \\
\text { in our MFI leading to credit uptake. }\end{array}$ & $\begin{array}{l}2 \\
(3.03)\end{array}$ & $\begin{array}{l}0 \\
(0.0)\end{array}$ & $6(9.09)$ & $\begin{array}{l}34 \\
(51.52)\end{array}$ & $\begin{array}{l}24 \\
(36.36)\end{array}$ & 4.181 & .83958 \\
\hline $\begin{array}{l}\text { More MFI branches has influenced } \\
\text { growth in Trade/wholesale and retail }\end{array}$ & $\begin{array}{l}0 \\
(0.0)\end{array}$ & $\begin{array}{l}3 \\
(4.55)\end{array}$ & $9(13.64)$ & $\begin{array}{l}34 \\
(51.52)\end{array}$ & $\begin{array}{l}20 \\
(30.3)\end{array}$ & 4.075 & .79053 \\
\hline $\begin{array}{l}\text { My organization has sufficient staff to } \\
\text { serve customers adequately }\end{array}$ & $\begin{array}{l}0 \\
(0.0)\end{array}$ & $\begin{array}{l}1 \\
(1.52)\end{array}$ & $\begin{array}{l}11 \\
(16.67)\end{array}$ & $\begin{array}{l}41 \\
(62.12)\end{array}$ & $\begin{array}{l}13 \\
(19.7)\end{array}$ & 4.000 & .65633 \\
\hline $\begin{array}{l}\text { There has been increase in number of } \\
\text { loans given to customers. }\end{array}$ & $\begin{array}{l}2 \\
(3.03)\end{array}$ & $\begin{array}{l}0 \\
(0.0)\end{array}$ & $\begin{array}{l}9 \\
(13.64)\end{array}$ & $\begin{array}{l}35 \\
(53.03)\end{array}$ & $\begin{array}{l}20 \\
(30.3)\end{array}$ & 4.075 & .84691 \\
\hline $\begin{array}{l}\text { Increased education and entrepreneurship } \\
\text { trainings }\end{array}$ & $\begin{array}{l}1 \\
(1.52)\end{array}$ & $\begin{array}{l}9 \\
(13.64)\end{array}$ & $\begin{array}{l}11 \\
(16.67)\end{array}$ & $\begin{array}{l}36 \\
(54.55)\end{array}$ & $\begin{array}{l}9 \\
(13.64)\end{array}$ & 3.651 & .93632 \\
\hline $\begin{array}{l}\text { Special loans products and services have } \\
\text { targeted marginal group such as women } \\
\text { and those excluded from conventional } \\
\text { banking }\end{array}$ & $\begin{array}{l}0 \\
(0.0)\end{array}$ & $\begin{array}{l}2 \\
(3.03)\end{array}$ & $\begin{array}{l}10 \\
(15.15)\end{array}$ & $\begin{array}{l}36 \\
(54.55)\end{array}$ & $\begin{array}{l}18 \\
(27.27)\end{array}$ & 4.060 & .74170 \\
\hline $\begin{array}{l}\text { There is unlimited withdrawal of savings } \\
\text { that fit with the demands of clients }\end{array}$ & $\begin{array}{l}0 \\
(0.0)\end{array}$ & $\begin{array}{l}2 \\
(3.03)\end{array}$ & $\begin{array}{l}12 \\
(18.18)\end{array}$ & $\begin{array}{l}33 \\
(50)\end{array}$ & $\begin{array}{l}19 \\
(28.79)\end{array}$ & 4.045 & .77324 \\
\hline $\begin{array}{l}\text { Cost of products and services of MFIs to } \\
\text { the clients are affordable in term of both } \\
\text { price costs and transaction costs }\end{array}$ & $\begin{array}{l}1 \\
(1.52)\end{array}$ & $\begin{array}{l}7 \\
(10.61)\end{array}$ & $\begin{array}{l}12 \\
(18.18)\end{array}$ & $\begin{array}{l}34 \\
(51.52)\end{array}$ & $\begin{array}{l}12 \\
(18.18)\end{array}$ & 3.742 & .93333 \\
\hline
\end{tabular}

\section{Source: Field Data, 2016}

The results in Table 1 reveal that majority of the respondents $(87.88 \%)$ confirmed that there has been increase customers base in their MFI leading to credit uptake as shown by 34(51.52\%) of the respondents who agreed and further $24(36.36 \%$ ) who strongly agree (mean score=4.1818, $\mathrm{SD}=.83958$ ). Increase in customer base is an indication of increase in breadth of outreach of MFIs as more clients are able to access credit for various investments. Likewise, more MFI branches has influenced growth in Trade/wholesale and retail in Kakamega County as shown by $34(51.52 \%$ ) of the respondents who agreed and 20(30.3\%) who strongly agree (mean score $=4.0758, \mathrm{SD}=0.79053$ ). Opening of branches especially to those MFIs which were visible in other parts of the country but not Kakamega County is an indication that credit services are brought closer to the citizen thereby contribute to increase in growth of trade.

Sufficiency staff is vital to reach out to unbanked or clients who are not aware of credit facilities that they may qualify for. Majority of the respondents agreed that their organization has sufficient staff to serve customers adequately as shown $41(62.12 \%$ ) and further $13(19.7 \%$ ) strongly agree (mean score $=4.000, \mathrm{SD}=0.65633$ ). Similarly, there has been increase in number of loans given to customers as shown by $83.3 \%$ of the respondents of which $35(53.03 \%$ ) agreed and $20(30.3 \%$ ) strongly agree (mean score $=4.0758, \mathrm{SD}=.84691$ ). The increase in loans and loan size is a measure of both depth and breadth of outreach. Increase in small sized loans is an indication of depth of outreach as more pro-poor client is targeted by MFIs.

Education and entrepreneurship trainings are non-financial services offered by MFIs so that credits are invested properly. The findings revealed that $36(54.55 \%)$ of the respondents agreed, $9(13.64 \%)$ strongly agreed while $36(54.55 \%$ ) were undecided (mean score $=3.6515, \mathrm{SD}=.93632)$. In bid to realize economic pillars for Vision 2030, MFIs need to reach out to entrepreneurship training and financial literacy before disbursing credit to small and micro-enterprises. This would ensure that credits advanced to clients are invested into useful ventures as well as improvement in repayment rates. Similarly, targeting groups of lender excluded from formal financial credit is risk and it has been considered by many studies as proxy of breadth of outreach. Majority of the respondents confirmed that special loans products and services have targeted marginal group such as women and those 
excluded from conventional banking as shown by $36(54.55 \%)$ of the respondents who agreed and $18(27.27 \%)$ strongly agree (mean score $=4.0606, \mathrm{SD}=0.74170)$.

Limited withdrawal limits ability of MFI clients to access credit when need thereby reduce the reachability of funds by the clients. Majority of the respondents $(78.79 \%)$ confirmed that there is unlimited withdrawal of savings that fit with the demands of clients while $12(18.18 \%$ ) were undecided (mean score $=4.0606, \mathrm{SD}=.74170)$. Lastly, 34(51.52\%) of the respondents agreed that cost of products and services of MFIs to the clients are affordable in term of both price costs and transaction costs and further 12(18.18\%) strongly agree while $12(18.18 \%)$ were undecided (mean score $=3.7424, \mathrm{SD}=.93333$ ).

\subsubsection{Secondary data}

Descriptive data was collected from MFIs financial statements between 2010 and 2013. For outreach (breadth and depth) and number of active borrowers, the mean, minimum, maximum and standard deviation is presented as shown in Table 2.

Table 2: Descriptive Data for Outreach

\begin{tabular}{lllll}
\hline Outreach Indicators & Minimum & Maximum & Mean & Std. Deviation \\
\hline Breadth Outreach & 1594.75 & 266203.00 & 46759.1833 & 69163.57154 \\
Depth Outreach & 6.33 & 76.81 & 23.3592 & 17.62021 \\
Average Loan Size & 164.75 & 2777.39 & 664.2904 & 636.12788 \\
\hline
\end{tabular}

\section{Source: Field Data, 2016}

Breadth of outreach

Breadth of MFI outreach measured by the number of active borrowers at any given period. The average number of active borrowers between 2010 and 2013 was 46,759 while the maximum was 266,203 and minimum 1,594. The MIX bench mark methodology classifies the breadth of outreach as large (greater than 30,000 number of borrowers), medium (10,000-30,000 number of borrowers), and small as having less than 10,000 number of borrowers (Kinde, 2012). The average breadth with over 30,000 borrowers indicates that the MFI outreach is largely serving the clients in the realization of vision 2030. On the other hand, Chemining'wa (2013) revealed that average number of borrowers has been declining since 2009 for 8 purposively selected microfinance institutions in Kenya.

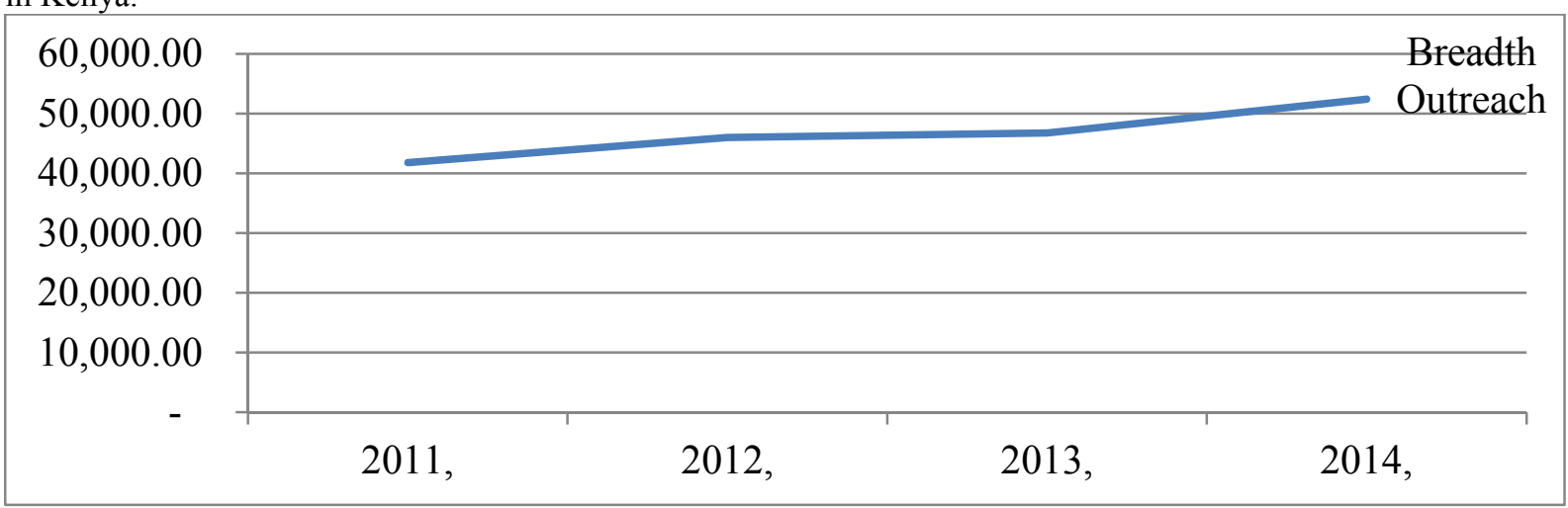

\section{Figure 1: Breadth of MFI outreach between 2010 and 2013 \\ Source: Field Data, 2016}

From Figure 1, there has been increase in average number of active borrowers from 2010 to 2013. This indicates that, more clients are joining MFI for credit uptake for various social-economic developments. Between 2010 and 2013, the percentage increase was 20.25\%. This reveals that MFI have been reaching out to more people over the years. This in agreement with Chepkorom (2013) who revealed there has been increase in number of clients as a result of range of microcredit products and their accessibility

\section{Depth of outreach}

Researchers have used average loan size per borrower as a proxy measure of depth of MFI outreach relative level of poverty (GNI) of the country (Wagenaar, 2012; Quayes, 2012; Schriener, 2002; Cull et al., 2007). The average depth of outreach was $23.3592 \%$ which are above 20 percent of per capita indicating that very poor clients were served by the MFIs between 2010 and 2013. The average depth shows that for a one currency unit per capita income earned, there is a loan outstanding of 23.3592 currency units i.e. a borrower can have a loan size nearly $23 \%$ his/her share from the total GDP. According to Mokaddem (2010), Kenya unlike other region has achieved depth of outreach due to a mixture of more low class and middle class borrowers. This is done with aim of achieving social mission and financial sustainability. 


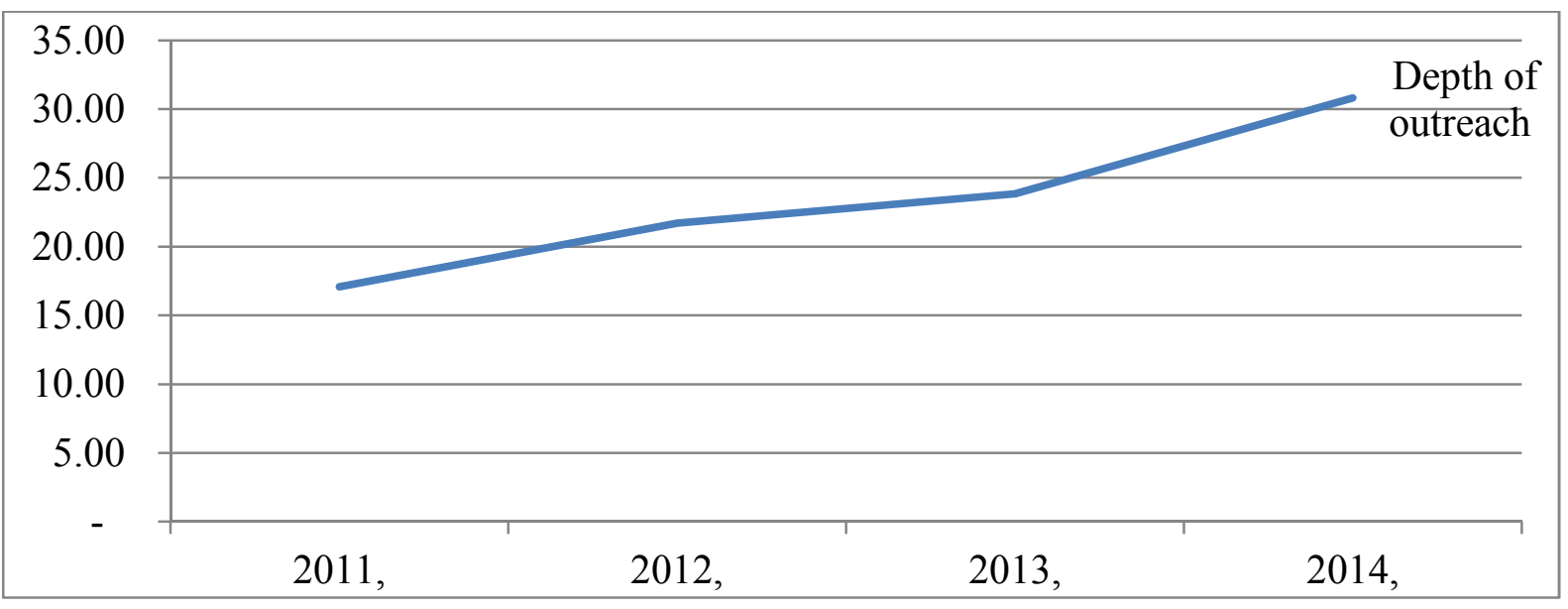

Figure 2: Outreach Depth between 2010 and 2013

Source: Field Data, 2016

Figure 2 reveals that there has been increase in MFI outreach depth from 2010 to 2013. From 2010 and 2013, the increase was $44.58 \%$ indicating that more poor people and groups have been reached by MFIs over the four years.

4.3.2 Correlational analysis between MFI outreach and the realization of economic pillar of vision 2030 Before further inferential analysis was conducted, it was necessary to conduct correlation tests to determine the existence, strength and direction of the linear relationship between the study variables. The relationship between MFI outreach, intervening variables and economic pillar of vision 2030 was significant and positive at $99.0 \%$ confidence level. The relationship between MFI outreach and economic pillars for vision 2030 is good, positive and statistically significant $(\mathrm{R}=.857, \mathrm{p}$-value $<.001)$. On intervening variables, the relationship between MFI outreach and GP, SE and PE is significant and positive as shown by $\mathrm{R}=.639$, $\mathrm{p}$-value $<.001 ; \mathrm{R}=.524$, $\mathrm{p}$-value $<.001$ and $\mathrm{R}=.701, \mathrm{p}$-value $<.001$ respectively. Similarly, the relationship between Economic pillars for vision 2030 and GP, SE and PE is significant and positive as shown by $\mathrm{R}=.596$, $\mathrm{p}$-value $<.001 ; \mathrm{R}=.522$, $\mathrm{p}$-value $<.001$ and $\mathrm{R}=.682$, $\mathrm{p}$-value $<.001$ respectively. This implies that, the intervening variables ( $\mathrm{PE}, \mathrm{SE}$ and GP) are significant mediating variable between MFI outreach and economic pillar for vision 2030.

\subsubsection{The relationship between MFI outreach and Economic pillars for Vision 2030}

Test of hypothesis $\mathrm{H}_{01}$

Ho1 There is no significant relationship between the MFI outreach on the realization of economic pillar of vision 2030

To test $\mathrm{H}_{01}$ a simple regression analysis was conducted. Data used to test this hypothesis was obtained by asking MFIs respondents the extent to which they agreed with various statements associated with MFI outreach and the MFIs client realization of economic pillar of vision 2030. The relevant results are presented Table 3.

Table 3: Regression results of MFI outreach on the realization of economic pillar of vision 2030.

\begin{tabular}{|c|c|c|c|c|c|c|}
\hline \multicolumn{7}{|c|}{ Model Summary and Coefficients } \\
\hline \multicolumn{7}{|c|}{ Model Summary and ANOVA } \\
\hline $\mathrm{R}$ & R Square & Adjusted R Square & Df & \multicolumn{2}{|l|}{$\mathrm{F}$} & Sig \\
\hline $.857^{\mathrm{a}}$ & .735 & .730 & 1,65 & \multicolumn{2}{|c|}{177.072} & $.000^{\mathrm{b}}$ \\
\hline \multicolumn{7}{|c|}{ Coefficients } \\
\hline \multirow[t]{2}{*}{ Model } & \multicolumn{2}{|c|}{ Unstandardized coefficients } & \multicolumn{2}{|c|}{ Standardized coefficients } & & \\
\hline & $\mathrm{B}$ & \begin{tabular}{l|l} 
& Std Error \\
\end{tabular} & Beta & & $\mathrm{t}$ & Sig \\
\hline Constant & 1.250 & .217 & & & 5.759 & .000 \\
\hline Outreach & .730 & .055 & .857 & & 13.307 & .000 \\
\hline
\end{tabular}

a. Dependent Variable: Economic pillar of vision 2030

b. Predictors: (Constant), MFI outreach

Source: Field Data, 2016

The results in Table 3 show that there is significant relationship between the MFI outreach on the realization of economic pillar of vision 2030. $(\mathrm{R}=0.867, \mathrm{P}<0.001)$. It explained $73.5 \%$ of its variation $\left(\mathrm{R}^{2}=.735\right)$. This implies that MFI outreach has a strong relationship with economic pillar of vision 2030. The overall model reveals a statistically significant relationship between predictor variable and the dependent variable $(\mathrm{F}=177.072$, $\mathrm{p}$-value $<.001)$ as shown. This further implies that there is a significant relationship between the predictor variable (MFI outreach) and realization of economic pillar of vision 2030

The unstandardized regression coefficient $(\beta)$ value of MFI outreach was 0.730 with a t-test of 13.307 and significance level of $\mathrm{p}$ value $<.001$. The results achieved objective one of the study and confirmed that MFI 
outreach had a statistically significant relationship with realization of economic pillar of vision 2030 as it explained $73.5 \%$ of its variation $\left(\mathrm{R}^{2}=.735\right)$. The regression equation to estimate the economic pillar of vision 2030 was stated as:

\section{Economic pillar of vision $=1.250+0.730 *$ MFI Outreach}

During interview and FGD session, the researcher noted that most of the MFIs have diversified their products. This included saving and loan products and borrowers were allowed to select products according to their ability. However, some of MFIs took long time to process the loans and interview with MFI officials revealed they take long time due to screening of risky clients before awarding loans. Similarly, discussants in FGDs revealed that the process fees were high and similar observation was observed with interest rate which made the clients to gain less from loans disbursed. Some of the respondents revealed that loan amount disbursed was not sufficient to cater for the purpose they applied for. The interview with MFIs officials revealed that they have conducted various training programme to various group such as youth and women. The aim of training was to ensure that loan is well invested so that they are able to repay on time and avoid taking of household items. The clients affirmed that they have been given training especially before loan disbursement and they indicated that more training and education is needed as most of them lack basic financial skills.

Having achieved the first objective, the study rejected the hypothesis that there is no significant relationship between the MFI outreach on the realization of economic pillar of vision 2030. This implied that there is significant relationship between the MFI outreach on the realization of economic pillar of vision 2030. The finding of this objective agrees with Pitt et al. (2003) who found out that MFIs outreach programme in Bangladesh led to capital accumulation, employment opportunities and higher income. In Thailand, Kaboski \& Townsend (2005) revealed that depth of outreach resulted increase agricultural productivity, asset growth and at same decrease in vulnerability. In Mexico, MFI outreach had positive impacts on employment and income as a result of business ownership (Bruhn \& Love, 2009).

However, using 13 MFIs in seven countries, Mosely and Hulme (1998) established inverse relationship between outreach and socio-economic development. Kondo (2007) found that microcredit had negative impact on poorer clients in Philippines. Banerjee et al. (2010) indicated MFI outreach had no positive impact on health, education and women empowerment. Similar results were obtained in India by Karlan \& Zinman (2009) among women borrowers. Bateman (2011) revealed that depth of outreach results to indebtness of poor borrowers especially in developing countries instead of pulling down out of poverty. The results were supported by Coleman (2006) and Kondo (2007) who found out that microcredit benefitted wealthier and more affluent clients in Thailand and Philippines respectively

During interview, MFIs officials revealed that commercialization of MFIs have forced them to charge maximum interest rate which limits their outreach especially average loan size. This was also revealed during FGDs where some of the respondents revealed that the interest rate were high as compared to SACCOs. The findings agree with Hubka and Zaidi (2007) who revealed that government plays key role in reaching out to the poor through offering grants to the MFIs. Cull, Demirgüç-Kunt and Morduch (2009) revealed that government regulation such as commercialization and interest rate ceiling influence larger average loan size and lending to women. The same was identified by Hartarska (2005) in Newly Independent states

\subsection{SUMMARY, CONCLUSION AND RECOMMENDATIONS 5.1 Summary of findings}

The objective of the study was to assess the influence of MFI outreach on the realization of economic pillar of vision 2030. The results indicated that MFI outreach had a statistically significant influence on the realization of vision 2030 in Kakamega. The hypothesis that there is no significant relationship between the MFI outreach on the realization of economic pillar of vision 2030 was rejected by the study. Most of the MFI had increased their customer through MFI breadth of outreach and special loans targeting marginal groups through depth of outreach. Secondary data from MFI revealed an increase in breadth of outreach as well as increase in depth of outreach between 2010 and 2013. The outstanding loan also revealed an increase in trend. The intervening variables jointly had significant influence on the relationship between outreach and realization of economic pillars for vision 2030. Political environment had highest significant influence of the three variables on the relationship between MFI outreach and realization of economic pillar for vision 2030.

\subsection{Conclusion}

The study concluded that MFI outreach had significant positive influence on the realization of economic pillar of vision 2030. This was achieved by MFI increasing the breadth and depth of outreach as well as involvement of training and education to their clients. Government policy and regulation made it easy for the poorer to access loans which were invested in agribusiness. 


\subsection{Recommendations}

From the conclusion, the following recommendations were made in respective to the objective of the study MFI Management

The study also recommends that MFIs should open more branches country wide in order to get closer to the people and hence increase the number of customers through diversity of services. Bring MFI services closer to the clients/borrowers would increase the uptake of credits which would in turn fasten the realization of economic pillar for vision 2030 thereby achieving social mission.

\section{Government}

Government need to ensure adequate provision of infrastructures like electricity which is basically required by the MFIs to carry out its operation, based on the findings that outreach increases together with increase in operating expense ratio therefore by providing necessary development, the efficiency of MFI would increase hence MFI sustainability.

\section{References}

Bereket, Z. \& Lalitha, R. (2009). Is There a Tradeoff between Outreach and ustainability of Micro finance institutions? Evidence from Indian Microfinance Institutions (MFIs). European Journal of Business and Management.

Brau, C., \& Woller, G. (2004). Microfinance: A Comprehensive Review of the Existing Literature. Journal of Entrepreneurial Finance and Business Ventures, Vol. 9, No. 1; pp. 1-26.

Brau, J. C. and Woller, G. M. (2004) „Microfinance: A Comprehensive Review of the Existing Literature. “ Journal of Entrepreneurial Finance and Business Ventures, 9(1), 1-26.

Bruhn,M., \& Love,I. (2009).The economic impact of Banking the unbanked: Evidence fromMexico (working paper no.4981). World bank policy research

Chemining'wa, T. (2013). The relationship between MFI outreach services and financial sustainability in Kenya. Master Thesis. University of Nairobi

Chepkorom Mercy Cherotich (2013). Role of Microfinance Institutions in financial deepening in Kenya Master Thesis. University of Nairobi

Chong, F. (2010). Evaluating the Credit Management of Micro-Enterprises. Department of Banking and Finance. University of Technology. MARA, 2(7), 149-158.

Chu M (2008). "Microfinance: Mobilizing Markets to Fight Poverty, The Latin American Experience." A Paper presented at Building Broad-Based Economic Growth Seminar 47th Annual Meeting of Inter-American Development Bank. Belo Horizonte: Brazil. March.

Coleman, Brett E. (2006). Microfinance in Northeast Thailand: Who Benefits and How Much? World Development 34 (9), 1612-1638.

Copestake, J., Dawson, P., Fanning, J., Mckay, A. \& Wright-Revolledo, K. (2007). Monitoring the diversity of the poverty outreach and impact of microfinance: a comparison of methods using data from Peru Development Policy Review Volume 23, Issue 6, 703-723.

Cull, R., Demirguc-Kunt, A. \& Morduch, J. (2006). Financial performance and outreach : a global analysis of leading microbanks. The World Bank. Available at: http://ideas.repec.org/p/wbk/wbrwps/3827.html [Accessed November 20, 2012].]

Giday, G., \& Chawla, S. (2015). Outreach and Sustainability of Microfinance Institutions of Ethiopia: A Case Study on Specialized Financial and Promotional Institution (SFPI). International Journal of Management and Commerce Innovations ISSN 2348-7585. Vol. 3, Issue 2, pp: (1024-1046)

GoK (2012). Second medium term plan, 2013 - 2017: transforming Kenya: pathway to devolution, socioeconomic development, equity and national unity. Government Printer. Nairobi

Hartarska, V. (2005), "Government and performance of microfinance institutions in Central and Eastern Europe", World Development, vol. 33, pp. 1627-43.

Hermes, N \& Lensink, R. (2011). Microfinance: Its Impact, Outreach, and Sustainability, World Development Vol. 39 , No. 6, pp. $875-881$

Honohan, P. (2004) .Financial Development, Growth and Poverty: How Close Are the Links?. World Bank Policy Research Working Paper 3203, February.

Hulme, D., \& Mosley, P. (1996). Finance Against Poverty. London: Routledge.

Iftekhar, A., Abul, B., Jamaliah, S., \& Mohd, F. (2014). Breadth of Outreach and Accountability of Microfinance Institutions (Mfis) In South Asian Region The Global Journal of Finance and Economics, Vol. 11, No. 2, (2014): 161-173

Jay, X. (2010). Competent managers: Handbook of management. Evans publishing company

Kavoo, A. (2013). The Effect of Outreach on the Growth of Microfinance Institutions in Nakuru County. Master Thesis. University of Nairobi

Khandker, S. R. (2006). Microfinance and poverty evidence using panel data from Bangladesh. Policy Research 
Working Paper Series 2945, The World Bank.

Kidzuga, A. (2013). The Relationship between Financial Sustainability and Outreach Of Microfinance Institutions In Kenya Master Thesis. University of Nairobi

Kinde,A. (2012). Financial Sustainability of Microfinance Institutions (MFIs) in Ethiopia,European Journal of Business and Management, Vol 4, No.15, 2012

Kimando, L. N., Kihoro, J. M., Njogu, G. W. (2012), Factors Influencing the Sustainability of Micro-Finance Institutions in Murang'a Municipality, International Journal of Business \& Commerce; Jun2012, p21

Kondo, T. 2007. Impact of Microfinance on Rural Households in the Philippines Operations Evaluation Department, Asian Development Bank.

Lafourcade, A., Isern, J., Mwangi, P. and Brown, M. (2005).Overview of the outreach and financial performance of microfinance institutions in Africa. MIX, 2005.

Magiri, A. (2014). Relationship between Outreach and Financial Performance of Deposit Taking Micro Finance Institutions in Kenya. Master Thesis. University of Nairobi

Malkawi, E., \& Atoom, R. (2011). Jordan Microfinance Institutions' Financial Viability to Achieve Microcredit Outreach, European Journal of Economics, Finance and Administrative Sciences ISSN 1450-2275 Issue 42, 2011

Meyer, J. (2002). Track record of financial institutions in assessing the poor in Asia. ADBresearch institute paper, No. 49, September 30, 2011.

MIX (2009), "Microfinance in Ethiopia", Microfinance Information Exchange (MIX) market, [Online] Available: http://www.mixmarket/mfi/country/Ethiopia ( October 2, 2011).

Morduch, J. (1998). Does Microfinance Really Help the Poor? Evidence from Flagship Programmes in Bangladesh. Hoover Institution, Stanford University (mimeo)

Morduch, J. (2000). The Microfinance promise. Journal of Economic Literature.pp1569 1614.

Morduch, J. (2005). The microfinance promise. J. Econ. Lit., XXXVII: 1579 -1614.

Mugenda, O.M. and A.G. Mugenda, (2008). Research methods: Quantitative and qualitative Approaches. Acts Press, Nairobi

Navajas, S., Schreiner, M., Meyer, R. L., Gonzalez-Vega, C. and Rodriguez-Meza, J. (2000). Microcredit and the poorest of the poor: theory and evidence from Bolivia, World Development, 26, 333-46.

Paxton, J. (2003). A poverty index and its application to Microfinance. Economics Bulletin, Vol.31,pp.143-8.

Quayes, S. (2012). "Depth of Outreach and Financial Sustainability of Microfinance Institutions." Applied Economics 44(26):3421.

Rosengard, J.K. (2001). Kinks in Links: Financial intermediation for Africa's poor. Africa Economic Policy Discussion Paper. 84. Boston: John F. Kennedy School of Government, Harvard University.

Schneider, F. (2002). Size and measurement of the informal economy in 110 countries. Paper presented at the Workshop of Australian National Tax Centre, ANU, Canberra.

Thapa, G.B., Chalmers, J., Taylor,K.W., and Conroy, J. (1999). Banking with the poor:report and recommendations based on case studies prepared by lending Asian banks and Nongovernmental organizations. FDC,Brisbane, Australia.

The National Economic and Social Council of Kenya (2007).The Kenyan vision 2030.Government Printer, Nairobi.

Tilahun, A. (2013). Determinants of Financial Sustainability of Microfinance Institutions in East Africa. European Journal of Business and Management. Vol.5, No.17, 2013

United Nations, (New York, United Nations, 2000) Microfinance and Poverty Eradication: Strengthening Africa's Microfinance Institutions. New York

World Bank. (2014). Kenya economic update: anchoring high growth - can manufacturing contribute more? Kenya economic update ; Edition no. 11. Washington, DC ; World Bank Group.

Zeller, M., \& Johannson, J. (2006). "Is There a Difference in Poverty Outreach by Type of Microfinance Institution? The Case of Peru and Bangladesh," Paper presented at the Global Conference on Access to Finance: Building Inclusive Financial Systems, World Bank and Brookings Institution, Washington D.C., May 30-31. 